УДК 657.6.02.16

DOI: https://doi.org/10.32782/2520-2200/2021-2-13

Морозова О.С. кандидат економічних наук, судовий експерт-економіст, докторантка кафедри міжнародних економічних відносин Прикарпатського національного університету імені Василя Стефаника

\title{
Morozova Olena
}

Vasyl Stefanyk Precarpathian National University

\section{ЗАСТОСУВАННЯ ЕКОНОМІЧНОЇ ЕКСПЕРТИЗИ В ДІЯЛЬНОСТІ СУБ'ЄКТІВ ГОСПОДАРЮВАННЯ}

\section{APPLICATION OF ECONOMIC EXPERTISE IN ACTIVITIES OF BUSINESS ENTITIES}

\begin{abstract}
У статті досліджено особливості та значення застосування економічної експертизи в діяльності суб'єктів господарювання Встановлено, що здійснення економічної експертизи в діяльності суб'єктів господарювання виступає одним із ключових інструментів в прогнозуванні беззбиткової діяльності, а також забезпеченні економічної безпеки. Визначено, що економічна експертиза діяльності суб'єктів господарювання має здійснюватися експертом, який має спеціальні знання та навички і може підтвердити їх сертифрікатом державного зразка. Доведено, що з метою забезпечення економічної безпеки суб'єктів господарювання необхідно враховувати їх географічне розташування, наявність природних ресурсів, забезпеченість трудовим потенціалом, а також не менш важливим $є$ забезпечення та здійснення постійних економічних експертиз на підприємстві з метою виявлення та попередження порушень котрі в результаті можуть призвести до значних фінансових втрат.
\end{abstract}

Ключові слова: експертиза, економічна експертиза, суб'єкти господарювання, економічна безпека, фрінансовий стан, аналіз.

В статье исследованы особенности и значение применения экономической экспертизы в деятельности субъектов хозяйствования. Установлено, что осуществление экономической экспертизы в деятельности субъектов хозяйствования выступает одним из ключевых инструментов в прогнозировании безубыточности, а также обеспечении экономической безопасности. Определено, что экономическая экспертиза деятельности субъектов хозяйствования должна осуществляться экспертом, который имеет специальные знания и навыки и может подтвердить их сертификатом государственного образца. Доказано, что с целью обеспечения экономической безопасности субъектов хозяйствования необходимо учитывать их географическое положение, наличие природных ресурсов, обеспеченность трудовым потенциалом, а также не менее важным является обеспечение и осуществление постоянных экономических экспертиз на предприятии с целью выявления и предупреждения нарушений которые в результате могут привести к значительным фринансовым потерям.

Ключевые слова: экспертиза, экономическая экспертиза, субъекты хозяйствования, экономическая безопасность, фринансовое состояние, анализ.

The article examines the features and significance of the application of economic expertise in the activities of economic entities. It is established that the implementation of economic expertise in the activities of economic entities is one of the key tools in forecasting break-even activities and economic security. It is determined that the economic examination of the activities of economic entities should be carried out by an expert who has special knowledge and skills and can confirm them with a state certificate. It is proved that in order to ensure the economic security of economic entities it is necessary to take into account their geographical location, availability of natural resources, labor potential, and equally important is the provision and implementation of permanent economic expertise at the enterprise to identify and prevent violations. lead to significant financial losses. It is established that the key task of economic expertise of economic entities, in generalized form, is to determine the level of development of the economic condition of economic entities during the period of economic activity. Economic examination of business entities should be carried out by an expert who has special knowledge and skills and can confirm them with a state certificate. Thus, economic expertise is a type of intel- 
lectual activity that is designed to solve the internal problems of economic entities, as well as improve the system of their management. In turn, economic expertise is costly for businesses, as it requires the involvement of highly qualified experts. In order to ensure the economic security of economic entities it is necessary to take into account their geographical location, availability of natural resources, labor potential, and equally important is the provision and implementation of permanent economic expertise at the enterprise to identify and prevent violations that can lead to significant financial losses. The key task of economic examination of the activities of economic entities, in general, is to determine the level of development of the economic condition of economic entities during the period of economic activity. The subject of this type of examination is to determine the relationship between the economic condition of economic entities with the consequences of the introduction of clear management decisions. Economic expertise is carried out through the use of special knowledge, skills and abilities of an expert economist in order to achieve the goal and solve clearly defined tasks related to accounting and tax accounting, financial and credit transactions, financial and economic activities. management projects.

Key words: examination, economic expertise, business entities, economic security, financial condition, analysis.

Постановка проблеми. Господарська діяльність вітчизняних підприємств вимагає ефективного та безперервного аналізу економічних процесів і явищ, котрі тісно пов'язані із становищем, в якому функціонує господарюючий суб'єкт та постійними змінами в законодавстві України. Дієвість господарювання підприємств виражається за допомогою ряду показників економічних, котрі в узагальненому вигляді свідчать про результативність діяльності, а також потенціал розвитку економічного суб'єктів господарювання. В ході оцінювання ефективності господарювання підприємства і пошуку шляхів ії покращення ключову роль відіграє точна організація економічної експертизи, саме не конфрліктної економічної експертизи. Адже аналізуючи економічну літературу стосовно досліджуваного питання, нами було встановлено, що переважна більшість наукових робіт присвячена саме судово-бухгалтерській експертизі. Судово-бухгалтерська експертиза здійснюється за клопотанням судово-слідчих органів з метою доведення фрактів порушення чинного законодавства, а не конфрлікту економічну експертизу, на нашу думку, доцільно проводити на підприємстві з метою моніторингу економічного стану та попередження негативних наслідків. Проте, в практичній діяльності необхідні підходи стосовно забезпечення чіткого здійснення аналітичних робіт виконуються частково, така ситуація негативно впливає на кінцевий результат фрінансово-господарської діяльності суб'єктів господарювання. Значна більшість господарюючих суб'єктів, котрі зустрілися із перешкодами, не вважають необхідним використання і важливість економічної експертизи. До того ж, набутий та сформований практичний. Також досвід практичної діяльності свідчить про те, що резерви економічної експертизи для вирішення таких проблем не реалізуються на значній кількості підприємств. Підсумовуючи вищенаведене варто наголо- сити на тому, що виникає необхідність в залученні кваліфікованих економістів, котрі можуть результативно проводити економічну експертизу суб'єкта господарювання та у чітко визначені строки розробляти можливі шляхи його виходу із ситуацій кризових.

Аналіз останніх досліджень і публікацій. Ключові аспекти застосування економічної експертизи в діяльності суб'єктів господарювання досліджували у своїх наукових працях такі вітчизняні та закордонні науковці як: Ларка М.І., Лісовські Г.О., Гавриш Г.О., Клименко Н.І., Федчишина В.В., Ткаченко С.О., Сосновська І.М., Безугла Л.С., Перевозова І.В.

Мета дослідження полягає у аналізі особливостей застосування економічної експертизи в діяльності суб'єктів господарювання.

Виклад основного матеріалу дослідження. Економічне становище суб'єктів господарювання $€$ комплексним поняттям, котре $€$ наслідком взаємодії усіх елементів в механізмі економічних відносин підприємства, пояснюється поєднанням фракторів виробничо-господарських та описується системою показників, котрі свідчать про наявність, розміщення і застосування ресурсів фінансових. За твердженням Ларка М.І. та Лісовські Г.О.: «головною метою фрінансової діяльності підприємства є отримання прибутків шляхом збільшення обсягів виробництва та реалізації продукції, нарощування власного капіталу й забезпечення стійкого фінансового стану. Для цього необхідно постійно підтримувати платоспроможність і рентабельність підприємства, і оптимальну структуру активу та пасиву балансу» [1, с. 169].

Враховуючи вищенаведене твердження, вважаємо, що здійснення економічної експертизи в діяльності суб'єктів господарювання виступає одним із ключових інструментів в прогнозуванні беззбиткової діяльності, а також забезпеченні економічної безпеки. Економічна експертиза являє собою складний та трудомісткий 
процес. У дослідницькій частині експертного висновку при вивченні об'єктів дослідження експерт вдається до використання різних методик. Під методами економічної експертизи доцільно розуміти сукупність застосовуваних експертом методичних прийомів (сорормованих на основі загальнонаукових методів і методів інформаційно-аналітичних наук) дослідження інфрормації про фракти фрінансово-господарської діяльності господарюючих суб'єктів. Здійснення економічної експертизи для суб'єктів господарювання буде затратним, але необхідним для подальшого фрункціонування.

За твердженням Гавриш Г.О.: «об'єктом економічної експертизи суб'єктів господарювання виступають матеріальні носії інформації економічного характеру (бухгалтерські дані та звіти, планові та аналітичні документи), в яких відображаються як позитивні, так і негативні зміни господарської діяльності підприємства» [2].

Ключовими завданнями економічної експертизи діяльності суб'єктів господарювання на думку Гавриш Г.О. є документальна обґрунтованість: «аналізу показників фрінансового стану (платоспроможності, фрінансової стійкості, прибутковості тощо); аналізу і структури майна і джерел його придбання; документальна обґрунтованість використання оборотних активів та джерел їх формування; аналізу джерел власних коштів та результатів фрінансово-господарської діяльності; аналізу загальногосподарських і спеціальних фондів; документальна обгрунтованість аналізу реальності розрахунків з дебіторами та кредиторами; аналізу економічної доцільності отримання та використання кредитів і позик; аналізу витрат і цін як чинників фрінансової стабільності та беззбитковості; розрахунків під час приватизації та оренди, відповідності чинним методикам оцінки вартості майна, що приватизується, та інших питань, пов'язаних з приватизацією, банкрутством підприємств; розрахунків частки майна при виході учасника зі складу засновників; розрахунків втраченого заробітку (від несвоєчасної виплати компенсації за заподіяну шкоду при втраті працездатності та в інших випадках); цільового витрачання бюджетних коштів; розрахунків втраченої вигоди» [2].

Підводячи підсумки аналізу вищенаведених тверджень зазначимо, що економічна експертиза діяльності суб'єктів господарювання має здійснюватися експертом, який має спеціальні знання та навички і може підтвердити їх сертифікатом державного зразка. Отже, економічна експертиза виступає видом інтелектуальної діяльності, котра покликана вирішити внутрішні проблеми суб'єктів господарювання, а також здійснює вдосконалення системи їх управління. В свою чергу економічна експертиза для суб'єктів господарювання є вартісною, адже вимагає залучення висококваліфікованих експертів.

На думку Клименко Н.І. і Федчишиної В.В.: «проведення економічної експертизи зумовлено потребою у спеціальних економічних знаннях із бухгалтерського обліку, оподаткування, контролю, аналізу результатів фрінансовогосподарської діяльності для забезпечення повноти, всебічності та об'єктивності дослідження фрактичних обставин справи» [3, с. 57].

Ткаченко С.О. у своїх працях зазначає: «основними завданнями експертизи економічного стану підприємства є такі:

- дослідження рентабельності й фрінансової стійкості підприємства;

- дослідження ефективності використання майна (капіталу) підприємства, забезпечення підприємства власними обіговими коштами;

- об'єктивне оцінювання динаміки та стану ліквідності, платоспроможності, фрінансової стійкості підприємства;

- оцінювання становища суб'єкта господарювання на фрінансовому ринку й кількісне оцінювання його конкурентоспроможності;

- аналіз ділової активності підприємства та його становища на ринку цінних паперів;

- визначення ефрективності використання фрінансових ресурсів" [4, с. 213].

Аналіз зазначених вище показників застосовуються $з$ метою забезпечення економічної безпеки суб'єктів господарювання в майбутніх періодах. Розглянемо детальніше сутність та ключові аспекти забезпечення економічної безпеки суб'єктів господарювання.

За твердженням І.М. Сосновської: «економічна безпека являє собою універсальну категорію, що відбиває захищеність суб'єктів соціально-економічних відносин на всіх рівнях. Економічна безпека підприємства - це захищеність його діяльності від негативних впливів зовнішнього середовища, а також спроможність швидко усунути різноманітні загрози або пристосуватися до існуючих умов, що не позначаються негативно на його діяльності. Зміст цього поняття містить у собі систему засобів, що забезпечують економічну стабільність підприємства, а також сприяють підвищенню рівня добробуту працівників» [5].

На думку Безуглої Л.С.: «успішний розвиток підприємництва можливий лише в умовах забезпечення здорової конкуренції, створення сприятливого клімату та раціональної підтримки з боку держави, ефрективної дії ринкових механізмів» [6, с. 7].

В умовах сьогодення ключовими проблемами суб'єктів господарювання в питаннях 
економічної безпеки є: нерегульована приватизація, банкрутство підприємств, котрі не витримують ринкової, а також не чесної конкуренції, системні проблеми в галузі оподаткування, порушення фінансової дисципліни.

3 метою забезпечення економічної безпеки суб'єктів господарювання необхідно враховувати їх географічне розташування, наявність природних ресурсів, забезпеченість трудовим потенціалом, а також не менш важливим $€$ забезпечення та здійснення постійних економічних експертиз на підприємстві 3 метою виявлення та попередження порушень котрі в результаті можуть призвести до значних фрінансових втрат. Встановлення зв'язку та порівняння фрункцій економічної експертизи та завдань системи забезпечення економічної безпеки суб'єктів господарювання представлено графічно на рисунку 1.
Аналізуючи рисунок 1, варто звернути увагу на те, що при зіставленні функцій економічної експертизи як інструменту протидії фрінансовим порушенням і завдань, що стоять перед системою забезпечення економічної безпеки суб'єктів господарювання, місце економічної експертизи в системі забезпечення економічної безпеки визначається як інструмент супроводу, що дозволяє виявити, попередити, запобігти, оцінити (ідентифрікувати джерело виникнення, ступінь небезпеки, об'єкт деструктивного впливу, величину збитку від загрози і ін.) конкретні (реальні і потенційні) форми прояву такої загрози економічній безпеці, як порушення в веденні фрінансової документації, а також сприяти у виборі заходів протидії їм.

Перевозова І.В. у своїх працях зазначає, що: «як вид дослідницької, аналітичної та прогнозної діяльності сучасний етап розвитку еконо-

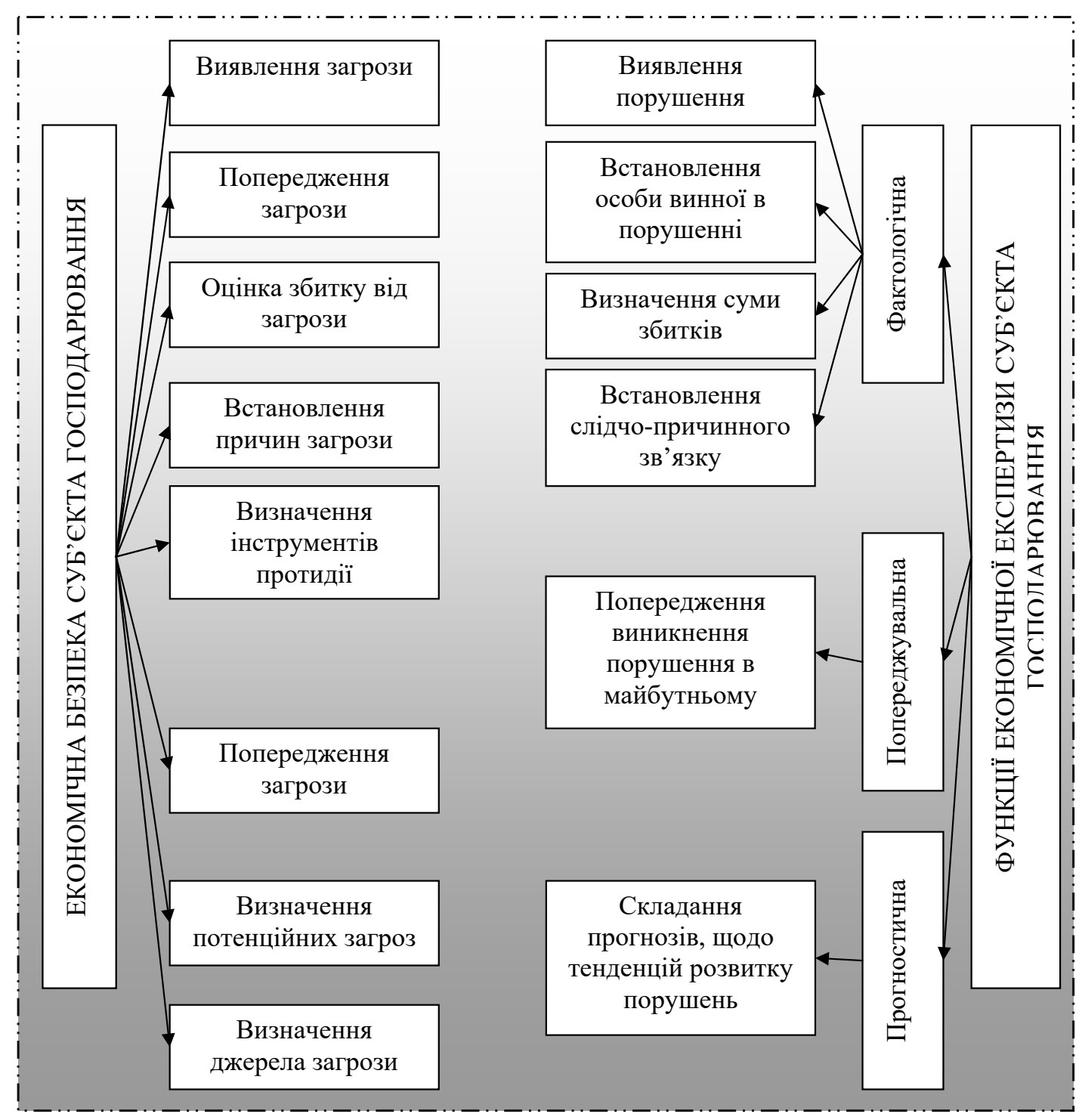

Рис. 1. Порівняння функцій економічної експертизи і завдань системи забезпечення економічної безпеки суб'єктів господарювання 
мічної експертизи поза рамками процесу судочинства здійснюється в двох основних формах:

- як елемент (стадія) процесу управління внутрішньовідомча, корпоративна, внутрішня експертиза;

- як вид консалтингової діяльності - незалежна (комерційна, замовна) зовнішня експертиза, що здійснюється незалежними експертами» [7, с. 99].

Варто зазначити, що ключовим завданням економічної експертизи діяльності суб'єктів господарювання, в узагальненому вигляді, виступає визначення рівня розвитку економічного стану суб'єктів господарювання за період здійснення господарської діяльності. Предметом даного виду експертизи є визначення зв'язків економічного стану суб'єктів господарювання із наслідками запровадження чітких управлінських рішень.

Висновки. Підводячи підсумки проведеного дослідження вважаємо за необхідне звернути увагу на те, що економічна експертиза в умовах сьогодення виступає надзвичайно дієвим інструментом моніторингу фінансово-господарського стану суб'єктів господарювання, а також важливим елементом в забезпеченні їх економічної безпеки. Результати економічної експертизи використовуються в якості основи при прийнятті управлінських рішень. Економічна експертиза відноситься до спеціалізованих експертиз. Економічна експертиза здійснюється за допомогою використання спеціальних знань, навичок і вмінь експерта-економіста 3 ціллю досягнення поставленої мети та розв'язання чітко визначених завдань, котрі пов'язані із веденням бухгалтерського і податкового обліку, операціями фрінансово-кредитними, діяльністю фрінансово-господарською суб'єктів господарювання. Перспективою подальших досліджень в галузі застосування економічної експертизи буде визначення ключових аспектів її здійснення у суб'єктів господарювання.

\section{Список використаних джерел:}

1. Ларка М.І., Лісовські Г.О. Аналіз фрінансового стану підприємства як засіб підвищення ефективності його діяльності. Вісник НТУ "ХПІ». Серія «Технічний прогрес і ефбективність виробництва». Харків : НТУ «ХПІ». 2013. № 22 (995). С. 168-174.

2. Гавриш Г.О. Сутність та особливості послуги з економічної експертизи. URL: http://nndes.org.ua/ news/item/53-сутність-та-особливості-послуги-з-економічної-експертизи.html (дата звернення: 19.04.2021).

3. Клименко Н.І., Федчишина В.В. Судово-економічна експертиза: сучасний стан і актуальні питання. Криміналіст. вісн. 2016. № 1. С. 56-61.

4. Ткаченко С.О. Фінанси підприємств : навч. посіб. Харків : Вид-во Харк. нац. ун-ту внутр. справ, 2008. 312 c.

5. Сосновська І.М. Поняття та значення економічної безпеки виробничо-господарської діяльності підприємств. № 9. 2015. URL:http://www.economy.nayka.com.ua/?op=1\&z=4303 (дата звернення: 18.04.2021).

6. Безугла Л.С. Державне регулювання розвитку малого та середнього підприємництва в умовах інфрормаційного суспільства : автореф. дис.. канд. наук з держ. управління : 25.00.02. Київ, 2011. $20 \mathrm{c}$.

7. Перевозова І.В. Економічна експертиза як соціальна галузь знань. Економіка: реалії часу. Науковий журнал. 2013. №3(8). С. 97-105.

\section{References:}

1. Larka M.I., Lisovsjki Gh.O. (2013) Analiz finansovogho stanu pidpryjemstva jak zasib pidvyshhennja efektyvnosti jogho dijaljnosti [Analysis of the financial condition of the enterprise as a means of improving the efficiency of its activities]. Visnyk NTU "KhPl». Serija "Tekhnichnyj proghres i efektyvnistj vyrobnyctva», no. 22 (995), pp. 168-174.

2. Ghavrysh Gh.O. (2014) Sutnistj ta osoblyvosti poslughy z ekonomichnoji ekspertyzy [The essence and features of the service of economic expertise]. Available at: http://nndes.org.ua/news/item/53сутність-та-особливості-послуги-з-економічної-експертизи.html (accessed 19 April 2021).

3. Klymenko N.I., Fedchyshyna V.V. (2016) Sudovo-ekonomichna ekspertyza: suchasnyj stan i aktualjni pytannja [Forensic economic examination: current status and current issues]. Kryminalist. visn., no. 1, pp. 56-61.

4. Tkachenko S.O. (2008) Finansy pidpryjemstv [Enterprise finance]. Kharkiv: Vyd-vo Khark. nac. un-tu vnutr. Sprav. 312 p. (in Ukrainian).

5. Sosnovsjka I.M. (2015) Ponjattja ta znachennja ekonomichnoji bezpeky vyrobnycho-ghospodarsjkoji dijaljnosti pidpryjemstv [The concept and importance of economic security of production and economic activities of enterprises]. Available at: URL: http://www.economy.nayka.com.ua/ ?op $=1 \& z=4303$ (accessed 18 April 2021) 
6. Bezughla L.S. (2011) Derzhavne reghuljuvannja rozvytku malogho ta serednjogho pidpryjemnyctva v umovakh informacijnogho suspiljstva [State regulation of small and medium business development in the information society] (PhD Thesis), Kyiv.

7. Perevozova I.V. (2013) Ekonomichna ekspertyza jak socialjna ghaluzj znanj [Economic expertise as a social field of knowledge]. Ekonomika: realiji chasu. Naukovyj zhurnal, no. 3 (8), pp. 97-105. 